\title{
Melanoma-Derived Growth Regulatory Protein
}

National Cancer Institute

\section{Source}

National Cancer Institute. Melanoma-Derived Growth Regulatory Protein. NCI

Thesaurus. Code C98126.

Melanoma-derived growth regulatory protein (131 aa, $\sim 15 \mathrm{kDa}$ ) is encoded by the human MIA gene. This protein plays a role in the repression of melanoma cell proliferation. 